удК 338.246 .86

\title{
ПРОГНОЗУВАННЯ ПОВЕДІНКИ СПОЖИВАЧІВ ТА ВИЗНАЧЕННЯ ІІІ ОСНОВНИХ ТРЕНДІВ ПІД ЧАС ПАНДЕМІї COVID-19
}

\section{FORECASTING OF CONSUMER BEHAVIOR AND DETERMINING ITS MAIN TRENDS DURING THE COVID-19 PANDEMIC}

\author{
Філатова Любов Сергіївна \\ кандидат економічних наук, старший викладач, \\ Вінницький національний технічний університет \\ ORCID: https://orcid.org/0000-0001-7713-307X \\ Благодир Лілія Миколаївна \\ кандидат економічних наук, доцент, \\ Вінницький національний технічний університет \\ ORCID: https://orcid.org/0000-0003-1685-3457 \\ Франчук Катерина Ігорівна \\ студент, \\ Вінницький національний технічний університет \\ ORCID: https://orcid.org/0000-0002-3879-776X
}

\author{
Filatova Liubov, Blagodur Lilia, Franchuk Kateryna \\ Vinnytsia National Technical University
}

\begin{abstract}
В зв'язку із змінами в економічному житті країни відбулась еволюція споживчих характеристик. Основною умовою виживання виробників та нормального функціонування є передбачення тенденцій в споживанні та визначення основних трендів в поведінці споживачів. Адже, споживачі відіграють ключову роль не лише в системі маркетингу компаній, а впливають на фрормування ринків, зміну виробничої та ринкової діяльності ринкових суб'єктів, їх ринкове положення. У статті проаналізовано вплив пандемії COVID-19 на зміну поведінки, уподобань та звичок українського споживача, визначено економічну доцільність даного дослідження. Дослідження описує поведінку споживачів, яка склалась протягом стадій сприйняття пандемії. Проаналізовані дані свідчать про те, що пандемія COVID-19 змінила потреби та поведінку покупців, а також їх рівень післяпродажного дисонансу. Нові задачі маркетологів - це завоювання лояльності споживачів, оскільки рівень задоволеності споживачів суттєво знизився. Надано опис нового маркетингового ландшафту після пандемії.

Ключові слова: поведінка споживача, пандемія, lockdown, COVID-19, тенденції споживчої поведінки, споживчий ринок, прогнозування поведінки споживачів.
\end{abstract}

В связи с изменениями экономической жизни страны произошла эволюция потребительских характеристик. Основным условием выживания производителей и нормального функционирования есть предсказание тенденций в потреблении и определение основных трендов в поведении потребителей. Ведь потребители играют ключевую роль не только в системе маркетинга компаний, а влияют на фрормирование рынков, изменение производственной и рыночной деятельности рыночных субъектов, их рыночное положение. В статье проанализировано влияние пандемии COVID-19 на изменение поведения, предпочтений и привычек украинского потребителя, определена экономическая целесообразность данного исследования. Исследование описывает поведение потребителей, которое сложилось на протяжении стадий восприятия пандемии. Проанализированные данные свидетельствуют о том, что пандемия COVID-19 изменила потребности и поведение покупателей, а также уровень послепродажного диссонанса. Новые задачи маркетологов - это завоевание лояльности потребителей, поскольку уровень удовлетворенности потребителей существенно снизился. Дано описание нового маркетингового ландшафта после пандемии.

Ключевые слова: поведение потребителя, пандемия, lockdown, COVID-19, тенденции потребительского поведения, потребительский рынок, прогнозирование поведения потребителей. 
The main global political and economic events that have taken place recently in Ukraine and in the world include the following: the global economic crisis, the confrontation between the economies of China, the EU and the United States; the election of the President of the United States and against the world's financial elites; the global COVID-19 pandemic; "Lockdown" of sectors of the world economy and individual countries; political and economic crisis in Ukraine, etc. Accordingly, these circumstances provoked negative consequences, first of all: the economic downturn in the country; deterioration of living standards; job cuts; rising unemployment; closure of certain activities and professions; closure of medium business; changes in the social status of the population and the growth of inflationary fluctuations. Against the background of global economic and political challenges, an evolutionary new round of the technological paradigm took place, which marked the transition from the analog world to the digital one. At the same time, any crisis leads to positive changes, such as: the emergence of new types of labor organization; new jobs and forms of activity; reduction of organizational and production costs. Changing phases of development of economic systems leads to transformations of components and processes, including during crises. The market environment is especially variable, so the priority of our study is to determine the behavior of consumers of the new formation. Due to changes in the economic life of the country, consumer characteristics have evolved. The main condition for the survival of producers and normal functioning is to predict trends in consumption and identify major trends in consumer behavior. After all, consumers play a key role not only in the marketing system of companies, but also influence the formation of markets, changes in production and market activities of market participants, their market position. The article analyzes the impact of the COVID-19 pandemic on changing the behavior, preferences and habits of Ukrainian consumers, determines the economic feasibility of this study. The study describes consumer behavior that has developed during the stages of pandemic perception. The analyzed data show that the COVID-19 pandemic has changed the needs and behavior of buyers, as well as their level of after-sales dissonance. The new task of marketers is to gain consumer loyalty, as the level of consumer satisfaction has decreased significantly. A description of the new marketing landscape after the pandemic is given.

Keywords: consumer behavior, pandemic, lockdown, COVID-19 trends in consumer behavior, consumer market, forecasting consumer behavior.

Постановка проблеми. До основних глобальних політичних і економічних подій, які відбулись останнім часом в Україні та в світі можемо віднести наступні: світову економічну кризу, протистояння економік Китаю, ЄС і США; вибори президента США та супротив світових фрінансових еліт; глобальна пандемія COVID-19; «lockdown» секторів світової економіки і окремих країн; політична та економічна криза в Україні тощо. Відповідно, ці обставини спровокували негативні насліди, перш за все: економічний спад в країні; погіршення рівня життя населення; скорочення робочих місць; зростання рівня безробіття; закриття певних видів діяльності та професій; згортання середнього бізнесу; зміна соціального статусу населення та зростання інфляяційних коливань. На фроні глобальних економічних та політичних викликів відбувся еволюційний новий виток технологічної парадигми, який ознаменував перехід з аналогового світу в цифровий. При цьому, будь яка, криза призводить й до позитивних зрушень, таких як: поява нових видів організації праці; нових робочих місць та форм діяльності; зменшення організаційних та виробничих витрат. Зміна фраз розвитку економічних систем призводить до транссрормацій складових компонентів та процесів, в т.ч. під час криз. Особливо мінливим $є$ ринкове середовище, тому пріоритетною задачею нашого дослідження $€$ визначення поведінки споживачів нового формування.
Аналіз останніх досліджень і публікацій. Попри високу актуальність та нагальність дослідження поведінки споживача під час пандемії COVID-19, варто відмітити, достатньо незначну кількість вітчизняних публікацій, які концентруються саме на маркетинговій складові, а не на макроаспектах. Також, варто відмітити достатній науковий інтерес в зарубіжних виданнях, проте, переважна більшість концентрують увагу на психологічній складовій та на стадіях сприйняття пандемії споживачами у їхній свідомості. Я. Бережний здійснює огляд споживчого ринку та особливості проходження карантину «COVID-19» в Україні. Автором було виокремлено таку тенденцію, як підтримка короткострокового (сезонного) відкладеного попиту в зв'язку 3 негативним соціально-економічним та психологічним тлом. Це в свою чергу спричинить стрімке згортання внутрішнього попиту. О. Пономарьовою сконцентровано основну увагу на 10 трендах поведінки споживачів після кризи.

Виділення невирішених раніше частин загальної проблеми. Пандемія COVID19 найсуттєвіша загроза для світової економіки, що спричинила негативні зовнішні та внутрішні екстерналії. Державне регулювання, в першу чергу стосувалось макрорівня та першочергових задач держави (охорона здоров'я населення, врегулювання цін, забезпечення товарами першої необхідності). 
Карантині обмеження в країні, економічна нестабільність, нестійкість національної економіки негативно вплинули на мезо-, мікрота нанорівні. В результаті чого виникли нові виклики та задачі, фрінансові хвилювання ринків, покриття негативних ефектів, які не враховано до державної підтримки. Очевидно, що збалансувати цю ситуацію підвладно лише інституту ринку, законам ринкового порядку та функціям конкуренції.

Формулювання цілей статті (постановка завдання). Дане дослідження вкрай важливе для підприємств, метою яких $є$ зміна стратегії розвитку та адаптація класичного інструментарію маркетингу до нових тенденцій на споживчих ринках. Саме гнучкість, мобільність, пристосування до нових фоорм ведення бізнесу дозволить стабілізувати ситуацію та уникнути фрінансової кризи.

Виклад основного матеріалу дослідження. Означимо чотири основні групи фракторів, які фрормують або порушують усталену поведінку та звички споживача: соціальні, науково-технічні, культурні та природогенні. До першої групи фракторів відносять вплив сім'ї, приналежність до певної референтної групи, соціальний статус та ін., до другої - розвиток науково-технічного прогресу та інноваційних технологій. Третя група базується на усталених нормах, традиціях, звичаях та цінностях як нації в цілому, так і окремого індивіда. Четверта група пов'язана 3 географрічним розташуванням, кліматичними умовами, некерованими природніми катастрофрами та глобальними пандеміями. Саме до цієї групи фракторів відноситься COVID-19 - інсрекційне захворювання світового масштабу, яке, без сумніву, $є$ найбільшою кризою для людства за останні 100 років. 3 початку поширення пандемії в Україні, як і у цілому світі, спостерігаються суттєві зміни у поведінці споживачів, про що свідчать дані опитування, проведеного цифровою агенцією Postmen. Так, 92\% респондентів стверджують, що їх життя значною мірою змінилось у зв'язку із запровадженням карантинних заходів. Варто відмітити, що ці зміни більшою мірою стосуються міського населення, зважаючи на можливість ведення відокремленого способу життя селян [1].

О. Пономарьовою [2] виділено 10 трендів поведінки споживача після кризи, а саме: відкладений попит як повернення звичної якості життя; посилення тренда усвідомленого споживання; повернення базової цінності «разом»; віддалена робота як нова реальність; новий work-life баланс; нові критерії прийняття рішення про покупку; продовження полювання за знижками; нове життя офрлайна в ритейлі; нові цінності при взаємодії з брендами і компаніями; соціальна відповідальність. Зокрема, на нашу думку, ключовими 3 них при формуванні поведінки споживачів нового типу є: «нові цінності при взаємодії 3 брендами і компаніями» та «соціальна відповідальність».

Дослідження Pandemic Culture від Canvas8 [3] виділяє шість глобальних змін: 1. Активна адаптація: об'єднання зусиль, використання існуючих інструментів нетрадиційними способами, збереження клієнтської бази бізнесом. 2. Загальна мобілізація для здійснення «добрих справ». 3. Масовий перехід в онлайн. 4. Обмежене споживання. 5. Усвідомлення колективної відповідальності: питання про баланс конфіденційності та контролю з боку уряду і здоров'я і поширення вірусу; люди стають обережнішими і усвідомлюють крихкість життя.6. Повернення довіри до фрактів: зростання довіри вченим і фрахівцям, боротьба з дезінфрормацією в соцмедіа, спроба усвідомити майбутнє.

В макроекономічному масштабі поведінка споживачів ілюстративно описується індексом споживчого настрою, зокрема на рис. 1 представлено дані за квітень 2020 р. Індекс споживчого настрою (за методикою University of Michigan Consumer Sentiment Index) $\epsilon$ показником економіко-поведінкових моделей та інтегрує в собі декілька індексів, які відображають загальне макроекономічне становище країни споживачем та його особистого матеріального становища.

Очевидно, що падіння індексу свідчить про почуття невизначеності серед споживачів і стратегію обережної споживчої поведінки. При цьому можемо відмітити, що при передбачені споживачами реальної ситуації та довготривалості кризової ситуації, значення проміжних індексів та агрегованого значно б змінилось.

Згідно з даними прес-служби Державної служби статистики України [5], реальні наявні доходи українців у 2 кварталі 2020 року скоротилися на 7,3\% у порівнянні 3 аналогічним періодом минулого року. Зазначається, що в зазначений період доходи населення України склали 867,5 млрд грн, у той час як витрати - 865,6 млрд грн. Відповідно приріст заощаджень склав 1,9 млрд грн. При цьому наявний дохід у розрахунку на одну особу становив 15566 грн (для порівняння, в 2 кварталі 2019 року цей показник становив 16345 грн). 


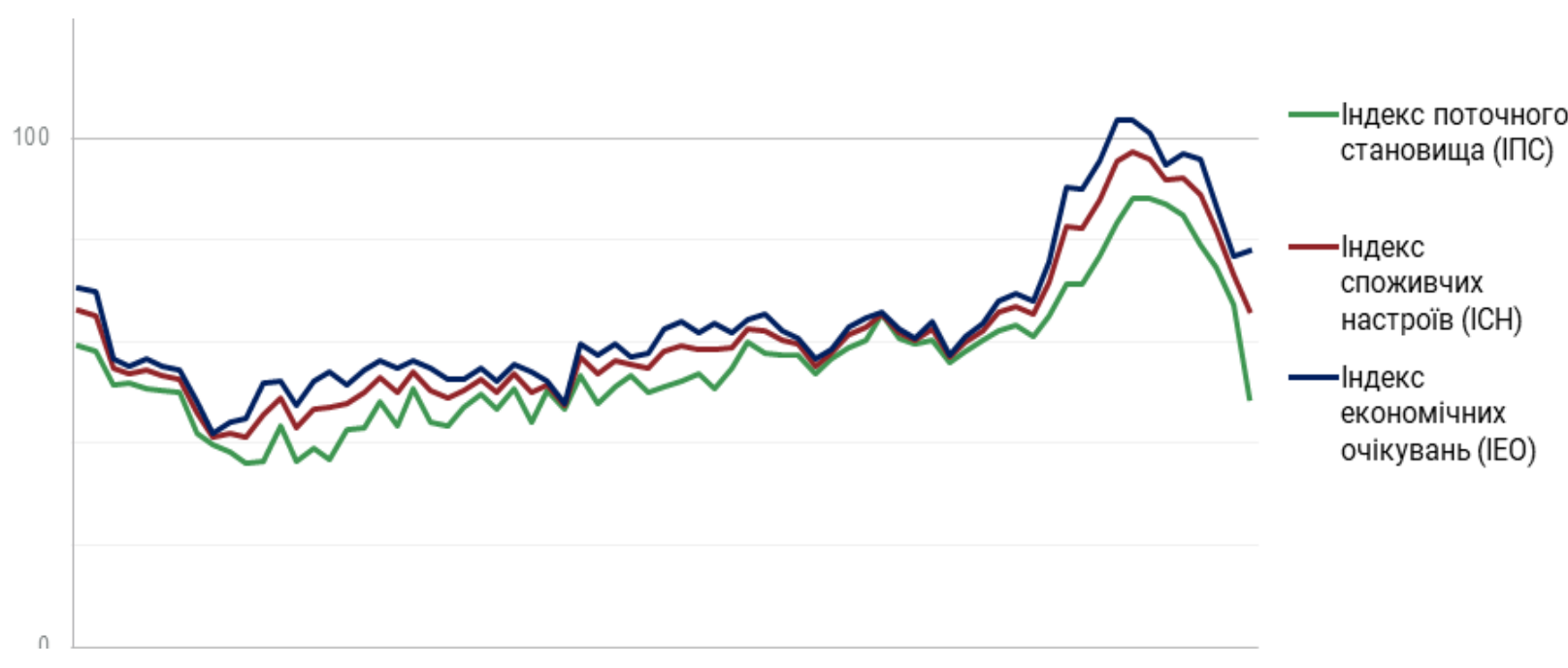

Рис. 1. Індекси споживчих настроїв в квітні 2020 р.

Джерело: [4]

При цьому, на фроні скорочення реальних доходів населення, спостерігається тенденція до зростання заощаджень. Влітку 2020 року НАБУ за участі компанії CBR [6] організувало дослідження, в результаті якого з'ясувалося, за час карантину частка тих, хто робить заощадження зросла, за 9 місяців 2020 року гривневі кошти українців у банках збільшилися на 54 мільярди гривень, або на 17\%, порівняно 3 минулим роком. Ріст заощаджень в період скорочення переважної кількості доходів свідчить про зміну поведінки громадян: скоротилася економічна активність, купівля товарів, більше проявляється режим заощадження, люди замислюються над майбутнім, як планувати своє життя в цих умовах.

Варто також відмітити, що споживачі мінімізували придбання та споживання товарів особливого попиту або послуг розважального характеру (кафре/ресторани, кінотеатри та ін.). Серед відкладених покупок лідирує придбання автомобілів, дороговартісної побутової техніки та нерухомості, про це заявили 47,2\% респондентів, 40,9\% відклали поїздки та відпустки, більше того, деякі українці призупинили на час карантину оплату послуг ЖКГ. Що стосується структури витрат, то 80,3\% українців відмітили, що лідерами у їх «карантинному кошику» $€$ продукти харчування. Ця тенденція пояснюється введенням карантинних обмежень (закриття ринків), які змусили споживача здійснювати оптові закупівлі у великих торгових мережах та необхідністю готувати вдома. Другу та третю позицію займають медикаменти та засоби гігієни, 37,2\% та 17,5\% відповідно [7].
За підсумками минулого року загальний обсяг продажу всіх категорій товарів «аптечного кошика» становив 114 млрд грн, або 4,2 млрд у доларовому еквіваленті, та 1,7 млрд упаковок. У порівнянні з 2019 роком цей показник зріс на 9,7\% в гривневому та на 2,2\% в натуральному вираженні. Найбільший приріст 2020 р. спостерігався у категорії «Медичні товари» - гуртом і в роздріб купують захисні маски, респіратори, санітайзери, пульсоксиметри, рукавички тощо [8].

У зв'язку з необхідністю працювати онлайн підвищився попит на програми, які забезпечують віддалений конфреренц-зв'язок: Zoom, GoogleMeet та інші, зросла популярність сервісів, які за допомогою штучного інтелекту дозволяють працювати з великими обсягами даних (наприклад, AmazonWebServices). Також збільшились витрати на послуги Internet, медіа послуги та мобільний трасрік. Зі збільшенням кількості активних користувачів мережі Інтернет намітилася стійка позитивна тенденція до зростання ринку електронної комерції. Так, покупки за допомогою інтернет-платорорм під час пандемії почали здійснюватись на 19\% частіше, але переважно за рахунок купівлі продуктів харчування та товарів щоденного попиту. При цьому кількість онлайн-споживачів не вплинула на цей показник, оскільки онлайнзамовлення зросли більшою мірою завдяки постійним користувачам, основу яких складає молодь. Встановлення режиму самоізоляції громадян помітно вплинуло на щоденні звички і поведінку споживачів щодо розширення використання електронних засобів (понад 70 \% українців почали використовувати їх частіше). 
Згідно 3 даними української продуктової IT-компанії EVO [9] загальна сума фрізичних товарів і послуг, які придбали українці в інтернеті у 2020 році, сягнула 107 млрд грн. Цей показник у порівнянні збільшився на $41 \%$. 3а попередній рік кількість замовлень на маркетплейсах EVO, a саме Prom.ua, Bigl.ua, Crafta. ua, Shafa.ua, IZI.ua та сайтах компаній Prom. uа зросла на 42\%, проте сума середнього чеку зменшилась на 10\%. Ця тенденція пояснюється тим, що кількість онлайн-покупок значно збільшилась, при цьому споживачі надавали перевагу дешевим товарам. Так наприклад, на головному маркетплейсі України Prom.ua найбільший приріст за січеньлистопад у порівнянні з аналогічним періодом припадає на такі категорії товарів: медичні товари - +225\% (844 тис. замовлень), сільгосптовари - +83\% (147 тис. замовлень), товари для домашніх тварин - +69\% (510 тис. замовлень), продукти харчування - +49\% (1,3 млн замовлень). Варто відмітити, що кількість онлайн-оплат за товари і послуги у минулому році зросла на понад 50\%. На маркетплейсах вже зараз приблизно 15\% розрахунків здійснюються карткою у момент покупки. 3 такими темпами за декілька років післяплата готівкою за придбані онлайн товари та оплата «на картку» втратять популярність, як менш безпечні і зручні.

У зв'язку з пандемією український споживач став активно використовувати послуги сервісів доставки. Так, за даними сервісу Glovo, вітчизняний ринок доставки у 2020 році зріс у 6-7 разів у порівнянні з минулим роком. Особливою популярністю почала користуватись доставка із супермаркетів, котра збільшилась майже у 15-18 разів. Лише за два тижні січня 2021 року кількість активних користувачів на платорормі зросла на 23\%, а найактивніший користувач за цей період скористався послугами сервісу Glovo 52 рази. Експерти прогнозують, що споживчий попит на послуги сервісів доставки збережеться й надалі, навіть після скасування карантинних обмежень [10].

В період пандемії представники б'юті індустрії зіштовхнулись з різкою зміною пріоритетів споживачів. Як і для інших категорій товарів характерною є реалізація косметики через інтернет-майданчики. Відтак, половина онлайн-продажів припадає на косметику по догляду за обличчям, тілом та волоссям. У зв'язку з регулярним використанням санітайзерів і частим миттям рук одним з найбільш потрібних товарів став зволожувальний крем для шкіри. У період карантину підвищився попит на товари для догляду та стайлінгу в домашніх умовах: фрарби для волосся, ножиці, тримери і машинки для стрижки, на продукти для зволоження і відновлення, креми, сироватки для обличчя і тіла, маски для обличчя. У Makeup, як і Brocard, відзначають уповільнення темпів продажу парфумерії [11].

Через постійне носіння захисних масок у світі різко знизилося використання губної помади наприклад, у Великій Британії у другому півріччі обсяги продажів цього б'юті-продукту впали на $49 \%$, а в Україні на 17\%. Натомість особливої актуальності для жінок набули засоби для макіяжу очей, такі як туш для вій, тіні, підводки, лайнери. Навіть так званий «індекс губної помади» за яким визначали зростання попиту на косметику під час кризи, аналітики пропонують перейменувати на «індекс туші для вій» або «індекс лаку для нігтів» [12].

Для узагальнення картини та можливості подальшого прогнозування варто виокремити ключові срактори, які $є$ основними критеріями для побудови унісрікованого портрету поведінки споживача під час пандемії COVID-19, до таких, ми вважаємо, за потрібне віднести: цілі; дозвілля/стиль життя; емоції/Страхи; мотивація; цінності та життєва позиція; знання; соціалізація; канали комунікації.

Представимо узагальнений портрет споживача під час пандемії COVID-19 табл. 1.

Перераховані критерії фрормуються фракторами внутрішнього та зовнішнього впливу. Зокрема, до останніх віднесемо: ситуаційні фрактори; соціокультурні фрактори; глобальні виклики; макроекономічне середовища; цифрове середовище; маркетингове середовище, які можна узагальнити до трьох основних груп: соціальні, науково-технічні, культурні та природогенні. До внутрішніх: психологічні та особистісні фрактори.

Висновки. Отже, можемо підсумувати деякі тенденції в поведінці споживача: компенсація та знаходження альтернатив на товари та послуги; зростання попиту на деякі види харчових продуктів; різке зростання/зниження попиту на певні групи товарів; зміна пріоритетів споживачів; особливий попит на товари актуальність, яких зросла під час пандемії; відмова від товарів та послуг, які втратили актуальність під час карантинних обмежень; схильність до заощадження; першочерговість придбання товарів першої необхідності; зміна масштабів (обсягів) та частоти придбання; зміна вектору споживання товарів; визначення пріоритетності в придбанні товарів; відмова від товарів особливого попиту, послуг 
Портрет споживача під час пандемії COVID-19

Таблиця 1

\begin{tabular}{|c|c|}
\hline Критерії & Характеристика \\
\hline Цілі & $\begin{array}{l}\text { - економія та мінімізація витрат; } \\
\text { - збереження робочого місця; } \\
\text { - збереження заробітньої плати; } \\
\text { - підтримка власного здоров'я та членів родини }\end{array}$ \\
\hline $\begin{array}{l}\text { Дозвілля/стиль } \\
\text { життя }\end{array}$ & $\begin{array}{l}\text { - work-life баланс; } \\
\text { - організація віддаленого робочого місця; } \\
\text { - приготування домашньої їжі; } \\
\text { - зростання кількості ремонтних робіт або виконання відкладених справ; } \\
\text { - збільшення часу на медіапослуги, Internet, Youtube та інше; } \\
\text { - відеоігри та інші цифрові хоббі; } \\
\text { - звичні та нові види хоббі }\end{array}$ \\
\hline Емоції/Страхи & $\begin{array}{l}\text { - можливість зараження COVID-19; } \\
\text { - власне здоров'я та членів родини; } \\
\text { - зниження заробітної плати або можливість скорочення; } \\
\text { - зростання цін; } \\
\text { - дефріцит товару на ринку }\end{array}$ \\
\hline Мотивація & $\begin{array}{l}\text { - обґрунтоване споживання; } \\
\text { - зменшення кількості раптових покупок; } \\
\text { - економія; } \\
\text { - відкладення дороговартісних покупок }\end{array}$ \\
\hline $\begin{array}{l}\text { Цінності та життєва } \\
\text { позиція }\end{array}$ & $\begin{array}{l}\text { - підтримка здорового способу життя; } \\
\text { - збереження родинних зв'язків; } \\
\text { - переосмислення надмірного споживацтва; } \\
\text { - збереження планети }\end{array}$ \\
\hline Знання & $\begin{array}{l}\text { - відвідування навчальних курсів та онлайн-тренінгів з метою освоєння } \\
\text { нової професії; } \\
\text { - література (книги та електронні носії); } \\
\text { - відео-уроки лекції, конореренції, курси; } \\
\text { - відео-екскурсії }\end{array}$ \\
\hline Соціалізація & $\begin{array}{l}\text { - збільшення спілкування зі сім'єю; } \\
\text { - збільшення впливу інфрлюенсерів; } \\
\text { - зменшення соціального впливу в зв'язку з карантинними обмеженнями }\end{array}$ \\
\hline Канали комунікації & $\begin{array}{l}\text { - соціальні мережі; } \\
\text { - інтернет контент та реклама }\end{array}$ \\
\hline
\end{tabular}

Джерело: розроблено авторами

розважального характеру, дороговартісних товарів та придбання товарів в іпотеку та кредит; перехід на цисррові продукти та послуги; прогнозування витрат; зміна звичних способів придбання; відкладений попит; полювання за знижками; нове життя офрлайн ритейлі.

Товари, що згадані вище можна віднести до спеціальних категорій, які виникли під час пандемії «панічні з короткостроковим едектом», «панічні 3 довгостроковим ефектом», «антистрес», «готую вдома», «повалені самоізоляцією». Також, варто зауважити, що перераховані вище тенденції до споживання певних товарів відповідає певній стадії сприймання населенням «lockdown». За результатами глобальних досліджень Nielsen покупці у країнах, охоплених вірусом, проходять шість стадій зміни споживацької поведінки: Стадія 1: Передчуття епідемії. Стадія 2: Проактивне піклування про здоров'я. Стадія 3: Підготовка до карантину. Стадія: 4: Карантин. Стадія 5: Життя, повне обмежень. Стадія 6: Нове нормальне життя.

Ряд вище перерахованих тенденцій, які спричинені карантинними обмеженнями носитимуть короткостроковий характер, зокрема попит на товари актуальність, яких зросла під час пандемії; різке зростання/зниження попиту на певні групи товарів; зміна пріоритетів споживачів та інші. Наприклад, за об'єктивним причинам зріс попит на товари по догляду за руками, також у період карантину підвищився попит на товари для догляду та стайлінгу в домашніх умовах; через постійне носіння захисних масок у світі різко знизилося використання губної помади, натомість особливої актуальності для жінок набули засоби для макіяжу очей. 
Проте, тенденції спричинені зміною споживацьких звичок та традицій; зміною стилю життя; зміною відношення до якості життя; зміною споживчих стандартів; набуття нових звичок та традицій споживачем; нові критерії прийняття рішення про покупку; обережна споживча поведінка; нові цінності при взаємодії з брендами і компаніями; соціальна відповідальність носитимуть довгостроковий характер.
Розмиття традиційних меж, переосмислення суспільством звичних традицій споживання, технологічні та інноваційні досягнення, маркетинг D2C створило нові споживчі звички. Перспективами подальших досліджень $€$ моделювання поведінки споживача на основі 3 фракторної моделі, яка скрадатиметься 3 наступних блоків: соціальне середовище; цисррове середовище та зміни споживчої структури.

\section{СПИСОК ВИКОРИСТАНИХ ДЖЕРЕЛ:}

1. Главные тренды на карантине: что изменилось в поведении украинцев. URL: https://www.epravda.com.ua/ rus/publications/2020/04/14/659337/ (дата звернення: 29.01.2021).

2. Пономарева Е. Потребитель после кризиса: 10 трендов. 10.04.2020. URL: https://marketmedia.ru/mediacontent/potrebitel-posle-krizisa-10-trendov-chast-2/ (дата звернення: 29.01.2021).

3. Pandemic Culture: the extraordinary impact of COVID-19 on consumer behaviour and what it means for you. URL: https://docs.google.com/presentation/d/1Frp7ZYFKNAGbUqHaXqQN9yHHNH6YggyTV90AC-2mn6U/ edit\#slide=id.g721c38cb47_0_1948

4. Індекс споживчих настроїв у квітні 2020 року зменшився на 6,8 п. і наразі становить 66,2. URL: https://sapiens.com.ua/ua/publication-single-page?id=123\#: :text=\%D0\%A3\%20\%D0\%BA\%D0\%B2\%D1\% 96\%D1\%82\%D0\%BD\%D1\%96\%202020\%20\%D1\%80\%D0\%BE\%D0\%BA\%D1\%83\%20\%D1\%96\%D0\%BD\% D0\%B4\%D0\%B5\%D0\%BA\%D1\%81,.\%2C\%20\%D1\%81\%D0\%BA\%D0\%BB\%D0\%B0\%D0\%B2\%D1\%88\%D 0\%B8\%2048\%2C8

5. Статистичні дані Державної служби статистики України. Офріційний сайт. URL: http://www.ukrstat.gov.ua/

6. Лебедина О. На чому економлять українці під час карантину - опитування. ZN,UA. 12.04.2020. URL: https://zn.ua/ukr/ECONOMICS/na-chomu-ekonomlyat-ukrayinci-pid-chas-karantinu-opituvannya-344419_html (дата звернення: 29.01.2021).

7. Бережний Я.В. Споживчий ринок і карантин «COVID-19» в Україні. Ефрективна економіка. 2020. № 9. DOI: https://doi.org/10.32702/2307-2105-2020.9.64

8. Кірсанов Д. Аптечний продаж за підсумками 2020 р. Щотижневик АПТЕКА. 25.01.2021. № 3 (1274). URL: https://www.apteka.ua/article/581310

9. Ярова М. Підсумки ринку електронної комерції в Україні по даним EVO: 107 млрд грн на покупки в інтернеті. AIN.UA. 25.12.2020. URL: https://ain.ua/2020/12/25/pidsumky-2020-evo/

10. Карпенко О. Итоги-2020. Как в пандемию развивались службы доставки. AIN.UA. 18.12.2020. URL: https://ain.ua/2020/12/18/itogi-2021-kak-razvivalis-sluzhby-dostavki/

11. Як вплинула пандемія на онлайн-магазини здоров'я і краси в Україні. URL: https://elnews.com.ua/uk/yakvplynula-pandemiya-na-onlajn-magazyny-zdorovya-i-krasy-v-ukrayini/ (дата звернення: 29.01.2021).

12. Модний вирок. Пандемія обвалила продажі губних помад - що буде з ринком косметики і який макіяж залишиться в тренді. URL: https://life.nv.ua/ukr/krasota-i-moda/doglyad-za-shkiroyu-oblichchya-stav-svitovimtrendom-v-sferi-kosmetiki-eksperti-50124532.html

\section{REFERENCES:}

1. Glavnyye trendy na karantin: chto izmenilos' $v$ povedenii ukraintsev [The main trends in quarantine: what has changed in the behavior of Ukrainians]. Available at: https://www.epravda.com.ua/rus/publications/2020/04/14/659337/ (accessed 29 January 2021).

2. Ponomareva E. (10.04.2020). Potrebitel' posle krizisa: 10 trendov [Consumer after the crisis: 10 trends]. Available at: https://marketmedia.ru/media-content/potrebitel-posle-krizisa-10-trendov-chast-2/ (accessed 29 January 2021).

3. Pandemic Culture: the extraordinary impact of COVID-19 on consumer behaviour and what it means for you. Available at: https://docs.google.com/presentation/d/1Frp7ZYFKNAGbUqHaXqQN9yHHNH6YggyTV90AC-2mn6U/ edit\#slide=id.g721c38cb47_0_1948

4. Indeks potrebitel'skikh nastroyeniy $v$ aprele 2020 umen'shilsya na 6,8 p. I seychas sostavlyayet 66,2 [The consumer sentiment index in April 2020 decreased by 6.8 points and now stands at 66.2]. Available at: 
https://sapiens.com.ua/ua/publication-single-page?id=123\#: :text=\%D0\%A3\%20\%D0\%BA\%D0\%B2\% D 1\%96\%D1\%82\%D0\%BD\%D1\%96\%202020\%20\%D1\%80\%D0\%BE\%D0\%BA\%D1\%83\%20 \%D1\%96\%D0\%BD\%D0\%B 4\%D0\%B5\%D0\%BA\%D1\%81, . \%2C\%20\%D1\%81\%D0\%BA\%D0\%BB\%D0\%B0\%D0\%B2\%D1\%88\%D0\%B8\%2048\%2C8

5. Statistical data of the State Statistics Service of Ukraine (Official site). Available at: http://www.ukrstat.gov.ua/

6. Lebedyna O. (12.04.2020). Na chomu ekonomlyat' ukrayintsi pid chas karantynu - opytuvannya [What do Ukrainians save on during quarantine - poll]. Available at: https://zn.ua/ukr/ECONOMICS/na-chomu-ekonomlyat-ukrayinci-pid-chas-karantinu-opituvannya-344419_.html (accessed 29 January 2021).

7. Berezhny Ya.V. (2020) Spozhyvchyy rynok i karantyn «COVID-19» v Ukrayini [Consumer market and quarantine "COVID-19" in Ukraine]. DOI: https://doi.org/10.32702/2307-2105-2020.9.64

8. Kirsanov D. Pharmacy sales following the results of 2020. Weekly PHARMACY, 25.01.2021, no. 3 (1274). Available at: https://www.apteka.ua/article/581310

9. Yarova M. (25.12.2020). Pidsumky rynku elektronnoyi kommertsiyi v Ukrayini po danym EVO: $107 \mathrm{mlrd}$ hrn na pokupky $v$ internet [Results of the e-commerce market in Ukraine according to EVO: UAH 107 billion for online purchases].

10. Karpenko O. Pidsumky rynku elektronnoyi kommertsiyi v Ukrayini po danym EVO: 107 mlrd hrn na pokupky v interneti. AIN.UA. Available at: https://ain.ua/2020/12/25/pidsumky-2020-evo/

11. Yak vplynula pandemiya na onlayn-mahazyny zdorov"ya i krasy v Ukrayini [How the pandemic has affected online health and beauty stores in Ukraine]. Available at: https://elnews.com.ua/uk/yak-vplynula-pandemiya-na-onlajn-magazyny-zdorovya-i-krasy-v-ukrayini/ (accessed 29 January 2021).

12. Modnyy vyrok. Pandemiya obvalyla prodazhi hubnykh pomad - shcho bude z rynkom kosmetyky i yakyy makiyazh zalyshyt'sya $v$ trendi [Fashionable sentence. The pandemic has ruined the sales of lipsticks - what will happen to the cosmetics market and what makeup will remain in trend]. Available at: https://life.nv.ua/ukr/ krasota-i-moda/doglyad-za-shkiroyu-oblichchya-stav-svitovim-trendom-v-sferi-kosmetiki-eksperti-50124532.html 